\title{
Bizarre Parosteal Osteochondromatous Proliferation
}

National Cancer Institute

\section{Source}

National Cancer Institute. Bizarre Parosteal Osteochondromatous Proliferation. NCI

Thesaurus. Code C121845.

\begin{abstract}
A benign lesion that usually affects the proximal small bones of the hands or feet. Grossly it consists of a cartilage cap and a bony stalk. Microscopically it is characterized by the presence of spindle cells, cartilage, and bone, usually in a disorg anized pattern compared to subungual exostosis. Enlarged (bizarre) chondrocytes are present in the cartilage. Swelling with or without pain is present. Recurrences following resection have been reported in approximately half of cases.
\end{abstract}

